\title{
A cladistic and comparative analysis of kinematic components of the fast-start of fishes, with a note on body size constraints
}

\author{
Caio Maximino - Amauri Gouveia $\mathbf{J r}$
}

Published online: 29 October 2008

(C) Springer-Verlag 2008

Erratum to: J Comp Physiol A

DOI 10.1007/s00359-008-0366-7

Amauri Gouveia Jr. was omitted from the list of authors. The correct list is given below. The authors apologize for this error.

C. Maximino $(\bowtie) \cdot$ A. Gouveia Jr

Laboratório de Neurociência e Comportamento, Centro de Ciências Biológicas, UFPA, r. Augusto Corrêa 01, 66075-110 Belém, PA, Brazil

e-mail: caio.maximino@gmail.com
A. Gouveia Jr
e-mail: agjunior@ufpa.br

The online version of the original article can be found under doi:10.1007/s00359-008-0366-7.

C. Maximino $(\square) \cdot$ A. Gouveia Jr

Laboratório de Neurociência e Comportamento,

Centro de Ciências Biológicas, UFPA, r. Augusto Corrêa 01,

66075-110 Belém, PA, Brazil

e-mail: caio.maximino@gmail.com

A. Gouveia Jr

e-mail: agjunior@ufpa.br 